\title{
Extreme Temperature Events Can Mitigate COVID-19 Morbidity in Warm Arid Environments: A Conclusion from Late Spring 2020 Heatwave in Egypt
}

\author{
Waleed Abbas* \\ Ayman Badawi** \\ Hossam Ismael $* *$
}

\begin{abstract}
The COVID-19 pandemic disease affects us all and get the world into an enormous crisis. Temperature is an important factor in infectivity reduction of viral disease. The current study screens the probable association between the extreme temperature events and COVID-19 outbreak. The most recent heatwave that hit Egypt in May 2020 selected as a case study. We studied the daily progression and current situation of COVID-19 morbidity in Egypt. The concurrent heatwave was identified and synoptically explained in deep. Considering the incubation-induced lag time between heatwave intensities and COVID-19 confirmed cases, visual interpretation of line graphs discovered an interesting identical connection between the real-time thermal intensities and the 14-day retreated infected cases during the heatwave days. The 5-day heatwave with thermal intensities $6.1-7.8{ }^{\circ} \mathrm{C}$ led to a 5-day fall in COVID-19 morbidity. The thermal intensity peak of the heatwave caused the greatest decline in COVID-19 confirmed cases by about onethird. The $2^{\text {nd }}$ order polynomial regression model for the relationship suggested that heatwave intensity of $5.5^{\circ} \mathrm{C}$ is the critical thermal threshold at which COVID-19 morbidity begins to be reduced, and $10.7{ }^{\circ} \mathrm{C}$ as a threshold of COVID-19 outbreak pause. It is concluded that heatwave of late spring can effectively restrict COVID-19 pandemic outbreak in warm arid environments like Egypt. COVID-19 is also highly expected to be restricted as the temperatures increase with the advance of summer season. It is recommended that lag time resulted from the virus incubation period must be considered in COVID-19 mortality and morbidity researches. [Bul. Soc. Géog. d'Égypte, 2020, 93: 1-24]
\end{abstract}

Key Words: Advection Heatwave, SARS-CoV-2, Pandemic Disease, Polynomial Regression, Synoptic Analysis.

\section{Introduction}

The Severe Acute Respiratory Syndrome CoronaVirus 2 (SARS-CoV-2), commonly known as Coronavirus or COVID-19, is a newly emerging infectious disease originally announced by China. First identified in late 2019, COVID19 Started from Wuhan City in the Hubei Province, eastern China (WHO,

* Department of Geography \& GIS, Ain Shams University, Cairo, Egypt.

** Physical and Numerical Research Department, Egyptian Meteorological Authority, Cairo, Egypt.

*** Department of Geography, New Valley University, Kharga, Egypt.

For Correspondence: e-mail: walid.abbas@art.asu.edu.eg 
Huang et al., 2020). It has been quickly spread in the vast territories of the country to be an epidemic. Over time, the contagion reached most of theglobe and the World Health Organizations (WHO) declaredthe COVID-19 outbreaks a public health emergency of international concern (PHEIC) on January 30, 2020, and an ongoing pandemic on March 11, 2020. By June 18, 2020, the official web-based dashboard dedicated to COVID-19 facts, provided by WHO, have been reported global accumulation of 8,223,454 confirmed infected cases, including 444,413 deaths (WHO, 2020a).

The COVID-19 pandemichas stretched to Africa in themiddle of February when the first infected case detected in Egypt (WHO, 15/2/2020). It has subsequently spread over all Egypt, with special virulence in Greater Cairo, which has inhabited by about 25 million people. COVID-19 outbreak in Africa is a very worrying issue since many healthcare systems on the continent are inadequate and having problems such as deficiency of equipment and funding, insufficient training of medical staff, and inefficient data transmission. It is feared that the pandemic could be difficult to keep under control in Africa, causing huge human losses, economic and financial crises if it spreads widely.

\section{- Literature Review, Scientific Gaps and Assumptions:}

Generally, epidemiological and environmental researchers have proposed that the respiratory diseases, like influenza, exhibit seasonality in incidence, spread and infection; i.e. higher incidence in the winter and a lower occurrence in warm seasons (Dowellet al., 2003; Dowellet al., 2004; Loh et al., 2011; Kudo et al., 2019). This is mainly attributed to climate-related conditions, particularly the atmospheric moisture and temperature. Although their adaptation capability to a wide range of thermal conditions, there are absolute limits of temperature viruses can tolerate. Since COVID-19 is a viral disease, an initial hypothesis was introduced assuming that the COVID-19 outbreak might weaken or fully stop in response to higher temperature observations as the advance of spring and summer days in the northern hemisphere.

The COVID-19 has been confirmed to have human-to-human and surface-to-human transmissibility (Wang et al., 2020). In both cases, the ambient thermal environment plays a major role in its survival and transmission. Previous experience decided that warm weather can reduce infectivity with human coronavirus (Lamarre \& Talbot, 1989; Tan et al., 2005; Casanova et al., 2010) and stop SARS (Wallis \& Nerlich, 2005). Similar conduct has been expected in the case of COVID-19 too, due to its relationship with the same family of coronavirus (Wilder-Smith et al., 2020). 
Just like coronavirus group (Chan et al., 2011; Van Doremalen et al., 2013), the survival time of COVID-19 pandemic on surfaces depends on temperature, and thus this could significantly influence the virus transmission risk (Ficetola \& Rubolini, 2020; Liuet, et al., 2020; Ma, et al., 2020; Oliveiros, et al., 2020; Tosepu, et al., 2020). In Wuhan, an association between meteorological factors and deaths number due to COVID-19 was found (Ma et al., 2020). Some studies indicated that the COVID-19 cases decreased with the temperature increasing (Oliveiros, et al., 2020; Tosepu, et al., 2020; Wang, et al., 2020). Temperature appeared as an important factor in COVID-19 infection in 429 cities around the world (Wang, et al., 2020).

Heatwave is a period of unusually hot weather or prolonged abnormally high temperatures relative to those expected (Abi-Samra, 2017; Matthews, 2018). Hence, it isanidealistic experimental period in which COVID-19 response to extreme temperatures could be examined. A scientific assessment indicates that the number and intensity of extreme events, such as heatwaves, are likely to increase as global temperatures continue to increase because of climate change (IPCC, 2013; Reddy, 2015). In Egypt, heatwaves mainly occur in May, June and August, and consequently, the highest numbers of heatwave days belong to these months.Heatwave is usually considered having additional risks on spreading disease and mortality (Johnson, et al., 2005; Medina-Ramon \& Schwartz, 2007; Isaksen, et al., 2016; Mendez-Lazaro, et al., 2016; Yin, et al., 2018). However, our perspective to heatwaves to different.

\section{- Research Objectives:}

Through analyzing the literary studies, it was recognized that the research on the relationship between heatwaves and COVID-19 spreadingis not available, especially in the case of warm arid regions. Wherefore, the urgency to better understand that relationship in developing countries is heightened when considering the near-term opportunities for intervention to interpret the reduction of confirmed people affected by the COVID-19. In addition, despite the efforts that have been made at global and national scales, the world has not developed safe and affordable vaccines or specific antiviral treatments for COVID-19 yet. Then, it is an extremely needful responsibility implementinganintensive researching movement, which helps establish a solid knowledge about COVID-19, and how the various environmental impacts could minimize or terminate its outbreak, particularly climate-based variables. Such information should be provided for policymakers.The present study has been undertaken with the following specific objectives (1) detectingand analyzing the most recent spring 
heatwave struck Egypt in mid-May 2020 and the synopticconditions contributed generating it. (2) discussing the progression and present situation of COVID-19 morbidity in Egypt. (3) examining if extreme temperatures could effectively diminish COVID-19 outbreak.

\section{Materials and Methods}

\subsection{Study Area:}

Egypt is a transcontinental country mostly located in northeast Africa, except theSinai Peninsula which occupies the southwest corner of Asia.With a total land area of about one million square kilometers, it overlooks the Mediterranean Sea in the north and the Red Sea in the east. It is bounded by countries of Sudan, Libya and occupied Palestine. Egypt is the most populated country in the Arab world and the third most populous on African, encompassing more than 100 million inhabitants. The capital region, Greater Cairo, is known as the largest urban agglomeration in Africa and the Middle East, where almostonefourth of Egypt's population resides in.

The major physical divisions of the country are North Coast, Nile Delta, Nile Valley, Western Desert, Eastern Desert, Red Sea Coast, Sinai Peninsula (Figure 1). The Nile River Valley and delta are Egypt's heartland; the home of more than $95 \%$ of the population. Spanning nearly 9.5 latitudes (between 22 to $31^{\circ} 37^{\prime} 28^{\prime \prime}$ north) and 12 longitudes (between 25 to $36^{\circ} 54^{\prime} 25^{\prime \prime}$ north), Egyptian territories extend within the hot-to-warm tropical and subtropical zones, where Tropic of Cancer passes through the southern region.

According to the Köppen climate classification map (Kottek et al., 2006), the desert climates fully rule Egyptian lands, where there is a large excess of evapotranspiration over rainfall amount, forming an extended arid zone as a part of the Sahara in Northern Africa. Desert climate has two variations inside; The hot desert climate $(\mathrm{BWh})$, which dominates the vast majority of the country; and the exceptional cold desert climate (BWk) centers only on a small area in south Sinai mountains, as made clear by the areal transparent colors in Figure (1). Generally, the country suffers warm summers and witnesses fairly mild winters. It is dominated by westerly winds which act as a temperature-moderating factor.

\subsection{Meteorological Data:}

In terms of extracting heatwave and analyzing its characteristics, we manipulated the hourly readings of standard two-meter air temperature to 
calculate the daily average of mean maximum temperature. The data forms a timeseries that persists a period of 45 days (May 1 to June 15, 2020). It was observed by "The Egyptian Meteorological Authority"; the official national meteorological service in Egypt. Moreover, 30-year daily normals of maximum temperature in the same 45 -day period were significant as a reference to which daily average is compared and heatwave brought out. The normals estimated based on daily meteorological data collected throughout the period 1990-2019.

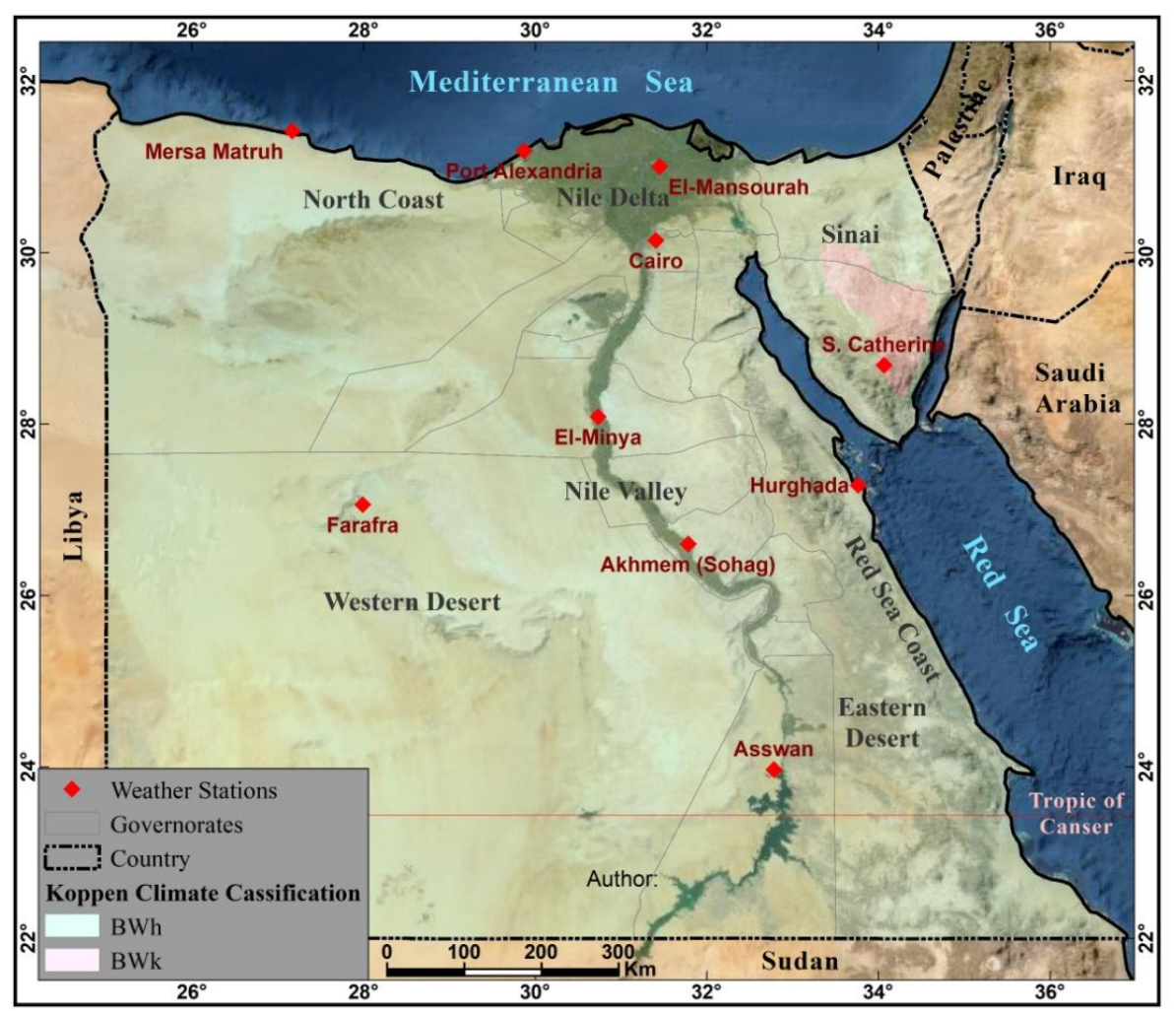

Credits: ESRI online world image.

Figure 1. Basic geographic settings of Egypt and the weather stations used.

Figure (1) displays locations of the surface climatological stations whose observations used in the study. Table (1) provides the basic metadata characterizing the stations. The selected stations seem to be welldistributed across the country and quite representative of all climate zones and substantial geographic regions inside, which were listed before in the study area section. 
Table 1. Basic metadata about the surface meteorological stations (chosen for the study - Data 1990-2019

\begin{tabular}{||c|c|c|c|c|c|c|c||}
\hline $\begin{array}{c}\text { WMO } \\
\text { ID }\end{array}$ & Name & Longitude & Latitude & $\begin{array}{c}\text { Geographic } \\
\text { Region }\end{array}$ & $\begin{array}{c}\text { Climate } \\
\text { Zone }\end{array}$ & $\begin{array}{c}\text { Elevation } \\
(\mathrm{m})\end{array}$ & $\begin{array}{c}\text { Distance to } \\
\text { Sea }(\mathrm{km})\end{array}$ \\
\hline 62304 & M. Matruh & 271007 & 312503 & North Coast & Hot desert & 25.0 & 2.94 \\
\hline 62315 & Port Alex. & 295206 & 311106 & North Coast & Hot desert & -3.4 & 0,03 \\
\hline 62343 & El-Mansurah & 312700 & 310000 & Nile Delta & Hot desert & 4.3 & 50.29 \\
\hline 62366 & Cairo AP & 312423 & 300821 & Nile Delta & Hot desert & 64.1 & 105.78 \\
\hline 62387 & Minya & 304400 & 280500 & Nile Valley & Hot desert & 37.1 & 235.11 \\
\hline 62397 & Sohag & 314700 & 263600 & Nile Valley & Hot desert & 61.4 & 216.18 \\
\hline 62414 & Aswan & 324700 & 235800 & Nile Valley & Hot desert & 194.2 & 243.56 \\
\hline 62423 & Farafra & 275921 & 270330 & W. Desert & Hot desert & 82.2 & 446.93 \\
\hline 62462 & Hurghada & 334600 & 271700 & E. Desert & Hot desert & 8.4 & 0.93 \\
\hline 62457 & S. Catherine & 340400 & 284100 & Sinai & Cold desert & 1349 & 50.37 \\
\hline
\end{tabular}

Credits: EMA, 1996 


\subsection{Heatwave Identification:}

Although it is a pervasive meteorological phenomenon (WMO, 2015), heatwave definition varies and there is no standardized approvedone (AbiSamra, 2017; Matthews, 2018). Table (2) reviews basic heatwave properties derived from the most popular definitions available in the literature. Some studies presented only a qualitative description, and not sufficient to develop practically statistical methodologies defining the heatwaves from daily temperature time series. However, based on a compilationof the definitions mentioned, a heatwave can be mentionedas "A risky atmospheric phenomenon occurs over a large area during a period when weather is much hotter than usual". The American Meteorological Society (AMS) glossary has been stated that the periodshould last at least 24 hours (AMS, 2012), but conventionally it usually spans several consecutive days to a few weeks (WMO, 2020b). The thermal abnormality dominating in the heatwave conflicts as well. Some definitions use temperatures alone or temperatures plus other meteorological elements, specifically humidity and wind speed.

Table 2. A review of heatwave aspects available in the literature.

\begin{tabular}{|l|l|l|l|}
\hline Author & $\begin{array}{l}\text { Thermal } \\
\text { Conditions }\end{array}$ & Duration(Area) & Reference \\
\hline WMO & $\begin{array}{l}\text { Daily maximum } \geq \\
\text { average by } 5{ }^{\circ} \mathrm{C}\end{array}$ & $\geq 5$ consecutive days & $\begin{array}{l}\text { Abi-Samra, N., } \\
2017\end{array}$ \\
\hline WMO & Marked warming & $\begin{array}{l}\text { few days - weeks } \\
\text { (large area) }\end{array}$ & WMO, 2020b \\
\hline WMO & Unusually hot & At least two to three days & WMO, 2015 \\
\hline $\begin{array}{l}\text { U.S National } \\
\text { Seather }\end{array}$ & Abnormally hot & Two days or more & $\begin{array}{l}\text { Abi-Samra, N., } \\
2017\end{array}$ \\
\hline $\begin{array}{l}\text { IPCC } \\
\text { AMS }\end{array}$ & Abnormally hot & Rare in time \& place & $\begin{array}{l}\text { Matthews, } \\
\text { J.B.R., 2018 }\end{array}$ \\
\hline $\begin{array}{l}\text { India Meteor. } \\
\text { Department }\end{array}$ & $\begin{array}{l}\text { Temperatures } \geq \\
\text { normal by } 5-6^{\circ} \mathrm{C}\end{array}$ & ---- & AMS, 2012 \\
\hline Frich, P. et al. & $\begin{array}{l}\text { Daily maximum } \geq \\
\text { normal by } 5{ }^{\circ} \mathrm{C}\end{array}$ & $>5$ consecutive days & $\begin{array}{l}\text { Frich, P. et al., } \\
2017\end{array}$ \\
\hline Burrows, A.T. & $\begin{array}{l}\text { Shade maximum } \geq \\
32.2{ }^{\circ} \mathrm{C}\end{array}$ & Three or more days & AMS, 2012 \\
\hline Robinson, P.J. & $\begin{array}{l}\text { Unusually heat } \\
\text { stress }\end{array}$ & Extended period & $\begin{array}{l}\text { Robinson, P.J., } \\
2000\end{array}$ \\
\hline Sfîca, L. & The $90^{\text {th }}$ percentile & Three consecutive days & Sfîca, L., 2017 \\
\hline
\end{tabular}

Credits: Compiled from multiple sources. 
Regarding the current study, we adopted a statistical recognition of heatwave from the daily maximum temperature record, which was synergistically derived from determinations provided by both WMO and AMS. Accordingly, the heatwave is any spell of at least one day, in which the daily maximum temperature surpasses the average maximum temperature by $5{ }^{\circ} \mathrm{C}$ or more. As brighten up, we used the WMO maximum temperature threshold as the only criterion to define the heatwave; a recommendation that was proven in many studies (Kent et al., 2014).

\subsection{Synoptic Analysis of Heatwave:}

Synoptic analysis of the mid-May heatwave under investigation ideally is a detailed study of the state of the atmosphere throughout the time of the extreme temperature event occurred. This is of a great importance to fully understand the forcing factors help generating the heatwave and controlling its behavior. The synoptic scale, also referred as large or cyclonic scale, needs to weather observations in form of synoptic charts; A map involving isopleths for various elements (temperature, pressure, surface wind and relative humidity), at a specific time, and over a vast area of $1000 \mathrm{~km}$ or more (AMS, 2012; Milard, 2018).

We obtained the synoptic weather data and charts based on ERA5-Land; A reanalysis dataset providing a consistent view of the evolution of land variables over several decades at an enhanced resolution compared to ERA5. ERA5Land has been produced by replaying the land component of the ECMWF ERA5 climate reanalysis. (https://cds.climate.copernicus.eu/cdsapp\#!/dataset/ reanalysis-era5-land?tab=form). It consists of the horizontal wind components (u-eastward \& v-northward), temperature (T), mean sea-level pressure (MSLP) and relative humidity $(\mathrm{RH})$ on regular latitude-longitude grid points with $0.1 \times 0.1^{\circ}$ resolution. Data is available at 1200 UTC. The extracted domain of study extended is the Middle East for the period May 19 to 24,2020 .

\subsection{COVID-19 data:}

The situation of COVID-19 morbidity in Egypt was assessed based on the official global statistics of WHO available for downloading on (https://covid19.who.int/). The dataset includes country-level daily infections number of COVID-19, expressed as "confirmed cases"; A person with laboratory confirmation of COVID-19 infection using a validated assay. Probable and presumptive confirmed cases were not taken into account. In addition, governorate-level data of COVID-19 confirmed cases provided by the Egyptian Ministry of Health (EMH) were involved, mainly to imply the spatial perspective in the discussion. 


\subsection{Lag Time Consideration:}

Medically speaking, the incubation period is a well-known technical term that refers to the time between exposure to the virus (becoming infected) and common symptoms onset. In our context of studying the response of COVID-19 morbidity magnitude to heatwave occurrence; the incubation period is extremely essential for the investigation. This is basically because there will not be a synchronization between the heatwave event and the related infected COVID-19 cases. Otherwise, a lag time would delay discovery of the relevant infected cases after certain days of incubation.

According to many sources (Backer, 2020; WHO, 2/4/2020, Zaki \& Mohamed, 2020), The incubation period for COVID-19can vary greatly, and it is on average 5-7.8 days. However, it can be up to 14 days.The latter is more consistent with a recent scientific paper (Lauer et al., 2020) announced that $97.5 \%$ of people infected with SARS-CoV-2 will exhibit symptoms by 11.5 days. Egyptian government is implementing mandatory 14-day quarantine periods forprobable cases and Overseas Arrivals. Consequently, therelationship analysis in the current study will beconducted between realtime temperature values observed during the heatwave versusthe 14-day retreated COVID-19 confirmed cases.

\subsection{Relationship Analysis:}

Line charts graphically representingday-to-day variations in temperature values (maximum and minimum averages) against COVID-19 morbidity count were substantial in the study. As a technique of analyzing data visualization, visual interpretation was initially employed to screen these charts in order to detect and realize the probable linkage between both variables, particularly when incubation-induced lag time is considered as the reason to desynchronization of them. Based on the visual interpretation of charts, heatwave and the relevant delayed drop in COVID-19 confirmed cases were strictly specified.Afterward, we deeply utilizedcorrelation, scatter plot and polynomial regression analysis to describe the quantitative impact of thermal extremes on the daily behavior of the COVID-19 outbreak. This can help identifying the critical threshold of heatwave intensity at which COVID-19 morbidity begins to decay. Simple linear regression was applied as wellto generalize the temporal progression of COVID19 new cases reported by WHO and EMH.

\section{Results and Discussion.}

\subsection{Synoptic analysis of mid-May heatwavecase study.}

Figure (2) is a line graph displays day-to-day thermal behavior of both average maximum temperature and the opposite 30 -year normal maximum temperaturein the meteorological stations under investigation during the 
period May 1 to June 15, 2020.Monitoring the daily variations of average maximum temperatures signalizes that an evident increase has started since May 13, forming an emergence of a relatively warm spell. It is obvious that average maximum temperature continuously elevated to record readings (on May 15) around $28.0{ }^{\circ} \mathrm{C}$ in the North Coast (Mersa Matruh and Port Alexandria), $35.0{ }^{\circ} \mathrm{C}$ in the Nile Delta (El-Mansourah), $37.5{ }^{\circ} \mathrm{C}$ in Cairo, $39.5{ }^{\circ} \mathrm{C}$ in the middle Nile Valley (Minya and Sohag), $42.1{ }^{\circ} \mathrm{C}$ in the upper Nile Valley (Aswan), $36.3{ }^{\circ} \mathrm{C}$ in the Western Desert (Farafra), $34.0^{\circ} \mathrm{C}$ in the Eastern Desert and the Red Sea coast (Hurghada), $35.6{ }^{\circ} \mathrm{C}$ in Sinai (Saint Catherine). Over a few days, temperatures excessed to extreme limits and average maximum temperatures reach highest on May 19-21, as Figure (2) illustrates. Observations reach $33.2-36.0^{\circ} \mathrm{C}$ in the North Coast, $41.1{ }^{\circ} \mathrm{C}$ in the Nile Delta, $44.4{ }^{\circ} \mathrm{C}$ in Cairo, 43.3-44.3 ${ }^{\circ} \mathrm{C}$ in the middle Nile Valley, $44.7^{\circ} \mathrm{C}$ in Aswan, $42.7{ }^{\circ} \mathrm{C}$ in the Western Desert, $36.5{ }^{\circ} \mathrm{C}$ in the Eastern Desert and the Red Sea coast, $38.5^{\circ} \mathrm{C}$ in Sinai.

The evolution of thermal conditions documented above in detail implicitly involved building up a severe heatwave event hit Egypt. Heatwave days were extracted, and heatwave intensities were calculated based on comparing the daily average of maximum temperatures to the reference record of 30-year normals of maximum temperatures. Figure (2) remarkably depicts the heatwave timestamp, where daily maximum temperature values much hotter than normal. Table (3) indicates that the mid-May heatwave lasted at most 6 successive days (16-21 May 2020), in which the difference between the daily average and normal (1990-2019) of maximum temperatures is $5{ }^{\circ} \mathrm{C}$ or more. The difference magnitude act as a thermal or heatwave intensity.

As shown in Table 3 that the heatwave occurrence was most pronounced in the Nile Delta, Cairo, middle Nile Valley and Western Desert regions, where the heatwave event continuously proceeded for 5-6 sequent days, and thermal intensities were the strongest $\left(7.0-8.4{ }^{\circ} \mathrm{C}\right)$ (Table 3). On the other hand, the heatwave was less powerful in the North Coast (intensities of 6-7.5 ${ }^{\circ} \mathrm{C}$ lasted for 2-5 days), and completely absent in regions of upper Nile Valley, Red Sea coast and Sinai; i.e. the difference between daily averages and normals of maximum temperatures is less than 5 ${ }^{\circ} \mathrm{C}$. The heatwave disappearance may be attributed to maritime effect in the Red Sea coast, and to the mountainous terrain in Sinai, and perhaps the higher temperature normal in Aswan (upper Nile Valley), the southernmost weather station in the study. 

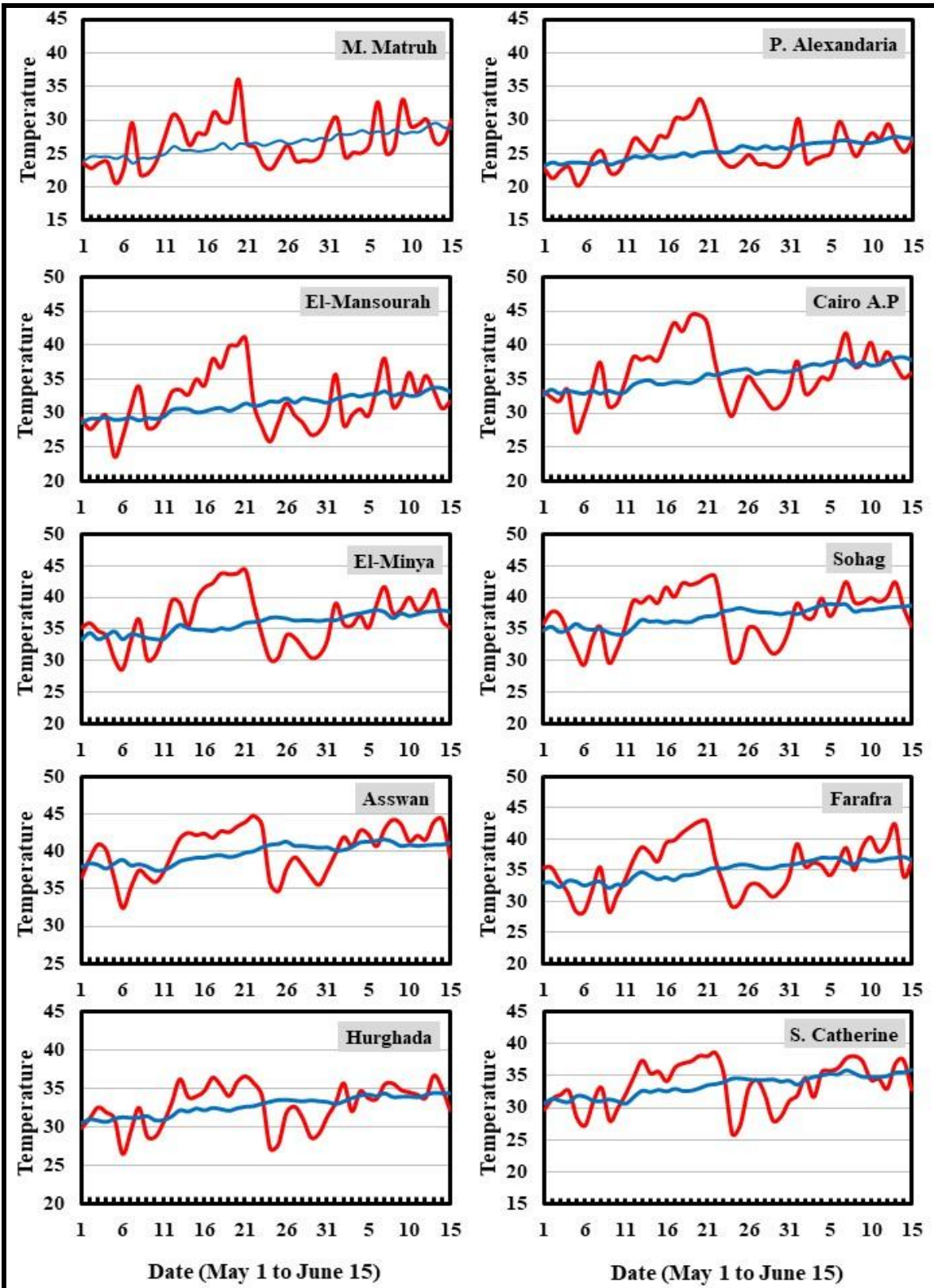

Daily maximum temperature

Normal maximum temperature

Credits: Calculation based on climate data.

Figure 2. Day-to-day thermal behavior of both daily and 30-year normal (19902019) of maximum temperatures in the meteorological stations used from May 1 to June 15, 2020. Heatwaves are successive days marked by daily maximum temperature values (red line) much hotter than normal (blue line) by $5{ }^{\circ} \mathrm{C}$ or more. 
Table 3. Thermal intensities during the heatwave days (16-21 May 2020). Thermal intensities expressing the difference between daily and 30-year normal (1990-2019) of maximum temperatures in the meteorological stations used.

\begin{tabular}{|l|c|c|c|c|c|c|c|c|}
\hline \multirow{2}{*}{ Stations } & \multicolumn{9}{|c|}{ Daily Intensity of the heatwave } & \multicolumn{2}{c|}{ Overall statistics } \\
\cline { 2 - 10 } & $\begin{array}{c}\mathbf{1 6} \\
\text { May }\end{array}$ & $\begin{array}{c}\mathbf{1 7} \\
\text { May }\end{array}$ & $\begin{array}{c}\mathbf{1 8} \\
\text { May }\end{array}$ & $\begin{array}{c}\mathbf{1 9} \\
\text { May }\end{array}$ & $\begin{array}{c}\mathbf{2 0} \\
\text { May }\end{array}$ & $\begin{array}{c}\mathbf{2 1} \\
\text { May }\end{array}$ & $\begin{array}{c}\text { Days } \\
\text { count }\end{array}$ & $\begin{array}{c}\text { Intensity } \\
\text { average }\end{array}$ \\
\hline M. Matruh & 2.5 & 5.4 & 3.2 & 4.2 & 9.5 & 0.2 & 2 & 7.5 \\
\hline Port Alex. & 3.0 & 5.6 & 5.1 & 6.3 & 8.0 & 5.0 & 5 & 6.0 \\
\hline El-Mansurah & 3.9 & 7.4 & 6.0 & 9.5 & 9.2 & 9.7 & 5 & 8.4 \\
\hline Cairo AP & 6.1 & 8.6 & 7.5 & 9.8 & 9.5 & 7.5 & 6 & 8.2 \\
\hline Minya & 6.7 & 7.5 & 8.6 & 8.7 & 8.4 & 8.3 & 6 & 8.0 \\
\hline Sohag & 5.6 & 3.8 & 6.1 & 5.9 & 5.7 & 6.2 & 5 & 5.9 \\
\hline Aswan & 3.2 & 2.4 & 3.2 & 3.3 & 3.9 & 4.1 & 0 & -- \\
\hline Farafra & 5.4 & 6.3 & 6.8 & 7.7 & 8.2 & 7.7 & 6 & 7.0 \\
\hline Hurghada & 2.5 & 3.9 & 3.1 & 1.9 & 3.4 & 3.9 & 0 & -- \\
\hline S. Catherine & 1.4 & 3.2 & 4.2 & 4.5 & 4.9 & 4.4 & 0 & -- \\
\hline
\end{tabular}

* Shaded cells indicate days out of the heatwave (thermal intensities less than $5{ }^{\circ} \mathrm{C}$ ).

Credits: Heatwave calculations based on climate data.

Synoptically, Figures (3) and (4) show the large-scale atmospheric conditions reign over Egypt and the Middle East during theheatwave days at 1200 UTC. This includes surface temperature, mean sea-level pressure, surface wind vector and horizontal distribution of relative humidity.Egypt's extreme weather events are fundamentally determined by the air mass properties. Unlike the prevailing northwesterly wind from the Mediterranean Sea blows predominantly over the country throughout the year and greatly moderates temperature values, the synoptic charts indicate that Egypt came in suffering from warm-to-hot northeasterly, southeasterly and southerly air masses coming from much hotter source regions (Arabian Peninsula and Sudan). As a result, the severe mid-May heatwave was triggered and lasted for 6 days (May 16 to 21) as of advective type (Sfîca, 2017; Barbier, et al., 2018).

The synoptic maps suggest that the heatwave arose from the extension of the Asian depression to the west, where the extremely hot air mass covering Iraq and eastern Syria extends to the eastern Mediterranean Basin and Egypt. This is India's Monsoon Low (IML); A huge thermal depression that affects three continents (Asia, Africa and Europe). This depression begins to form on Indian land surfaces in April and ends in September. 


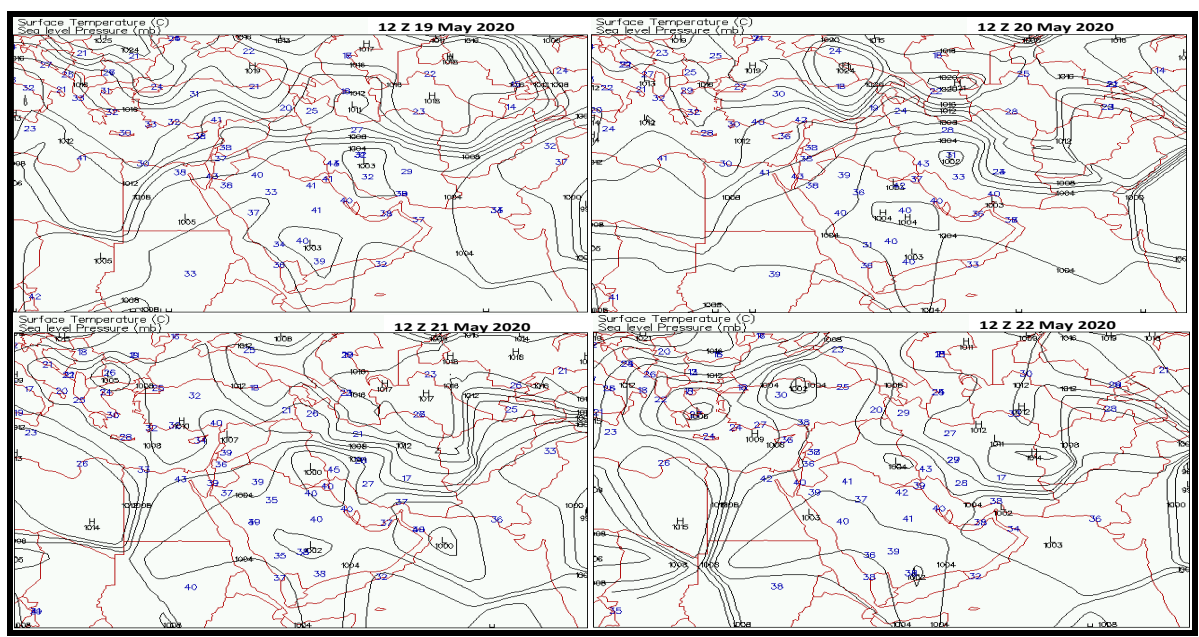

Credits: https://cds.climate.copernicus.eu/

Figure 3. Synoptic chart of surface temperature (blue number) and MSL pressure (black isopleth) over Egypt from May 19 to 21, 2020 at 1200 UTC.

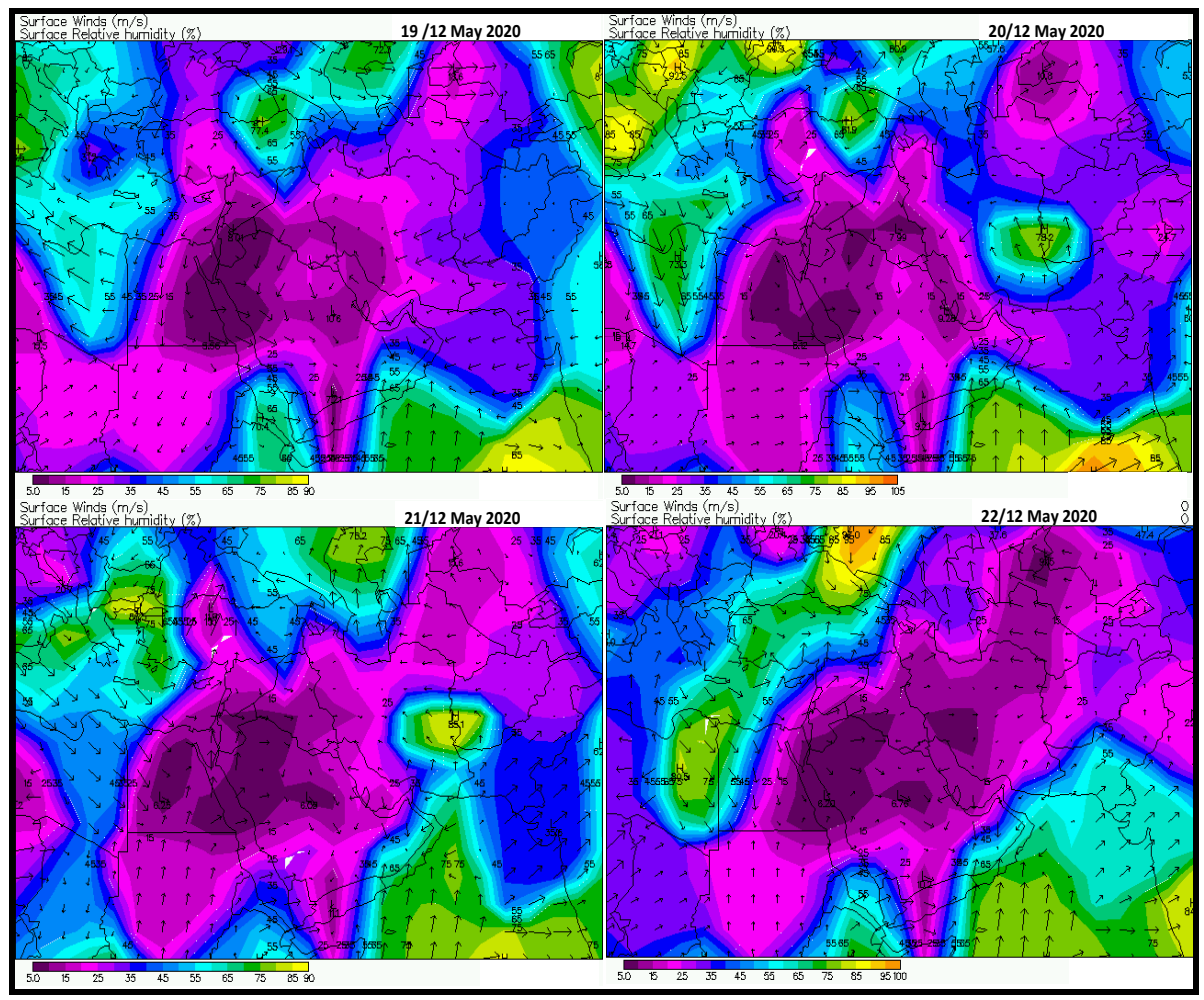

Credits: https://cds.climate.copernicus.eu/

Figure 4. Synoptic chart of surface wind (vector) and horizontal distribution of relative humidity (shaded) over Egypt from May 19 to 22, 2020 at 1200 UTC. 
In addition to the IML, the hot southerly and southeasterly winds, contributing generate the thermal abnormality, mainly driven by the intrusion and intensification of Sudan Monsoon Low (SML) from east Africa towards southern Egypt, supplies the region with hot winds and motivates thundery conditions (El-Fandy, 1948). This low is a northward extension of larger-scale low pressure zone covers a vast area of tropical Africa. It is formed through rapid heating of the land surface and active convection currents in the Equatorial region. The heatwave began to recede with the IML backward to the east and a noted extend of the subtropical high pressure over whole Egypt.

\subsection{Situation of COVID-19 morbidity in Egypt:}

Egypt reported its first confirmed case of COVID-19 in mid-February. This is the second country in the WHO Eastern Mediterranean Regional Office (EMRO) to confirm a case, and the first reported case from the African continent (WHO, 15/2/2020). Although African countries constitute just a small percentage $(2.4 \%)$ of the overall universal outbreak, Egypt ranks second with COVID-19 infectivity, surpassing 50 thousand accumulated people infected, follows about 80.4 thousand accumulated cases exist in South Africa. Egypt as well is in the second place among the Arab states, after Saudi Arabia which includes 141.2 infections (WHO, 2020).

On June 22, thehealth registration and monitoring documented that Egypt detected 1576 new coronavirus cases, giving a total infection tally of 56809 since the outbreak beginning. The line chart in Figure (5) plots dayto-day progression of COVID-19 newly confirmed incidents in Egypt throughout the period of interest (May 1 to June 15). The graph obviously indicates that there has been a steady increase in infection count recorded. The trend line emphasizes this fact, where a general upward tendency of COVID-19 outbreak can be noticeably observed.

Nevertheless, a deep examination can disclose more detailedup and down fluctuations, which constitute major components of thedaily infection advancement. As pointed outon the chart, the daily infections development achieved its main peakon May 31, when 1536 confirmed cases detected after a continuous rise of morbidity. Immediately there after, an abrupt decline of COVID-19 infection numberis distinguishable, and the main drop occurs with only 1079 cases on June 3. To illustrate this further, a reduction in the daily confirmed numbers infected with coronavirus to 1399 on June 1, 1152 recorded on June 2, 1079, recorded on June 3, 1155 recorded on June 4 and 1348 recorded on June 5. Gradual increase behavior of COVID-19 contagion is regained once again and persisting to the end of the selected period (June 15). 


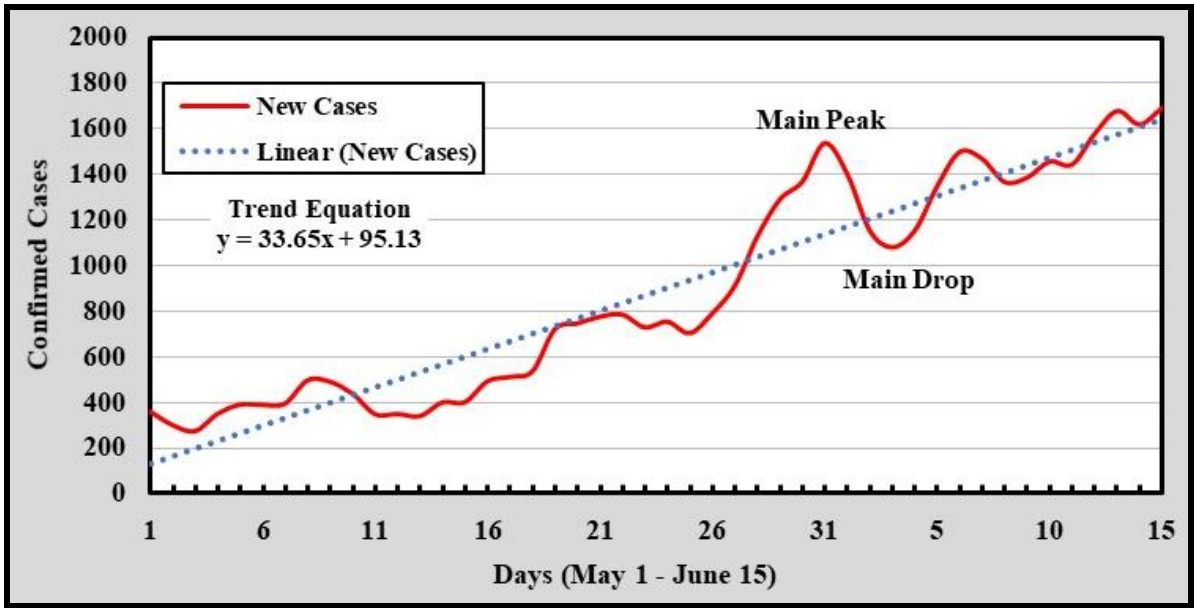

Credits: Based on COVID-19 data (https://covid19.who.int/)

Figure 5. Daily advancement of COVID-19 confirmed new cases and linear trendfrom May 1 to June 15, 2020. Main peak and drop on the graphical line indicated.

Concerning the spatial perspective of COVID-19 pandemic outbreak in Egypt, official reports released by EMH for the number of confirmed cases by governorates are substantially significative. All governorates and major geographic divisions were documented as infected. The triple-governorate capital region has the largest infectivity ever, where Cairo, Giza and Qalyubiahave been on top of the list; containing just less than fifty percent (46.2\%) of the total accumulated cases. Menofia (Nile Delta region) and Fayoum (Middle Nile Valley region) governorates rank in fourth and fifth places, containing $6.2 \%$ and $5.2 \%$ respectively. On theother hand, governorates located in regions of Sinai, North Coast, Western and Eastern Deserts and Red Sea Coast are generally the least infected.

\subsection{Heatwave impact on COVID-19 morbidity:}

Figure (6) displays graphical lines associating between daily advancement of both real-time heatwave thermal intensities and concurrently registered cases of COVID-19 in the whole Egypt. Initial visual screening of the possible connection may not suggest any sensible consistency found between the daily behavior of the graphs. Logically, the virus incubation period is 14 days according to WHO reports, and a lot of newly published research. This means that the effect of the heatwave will be monitored within 14 days after the end of it. So, Given the 14-day incubation period of becoming infected with COVID-19 to symptoms onset, and the consequently lag time that is shown in Figure (6), a profound discovery can be recognized. Interestingly, we found an identical relationship between thermal intensities during heatwave days and the delayed COVID-19 new cases detected. 


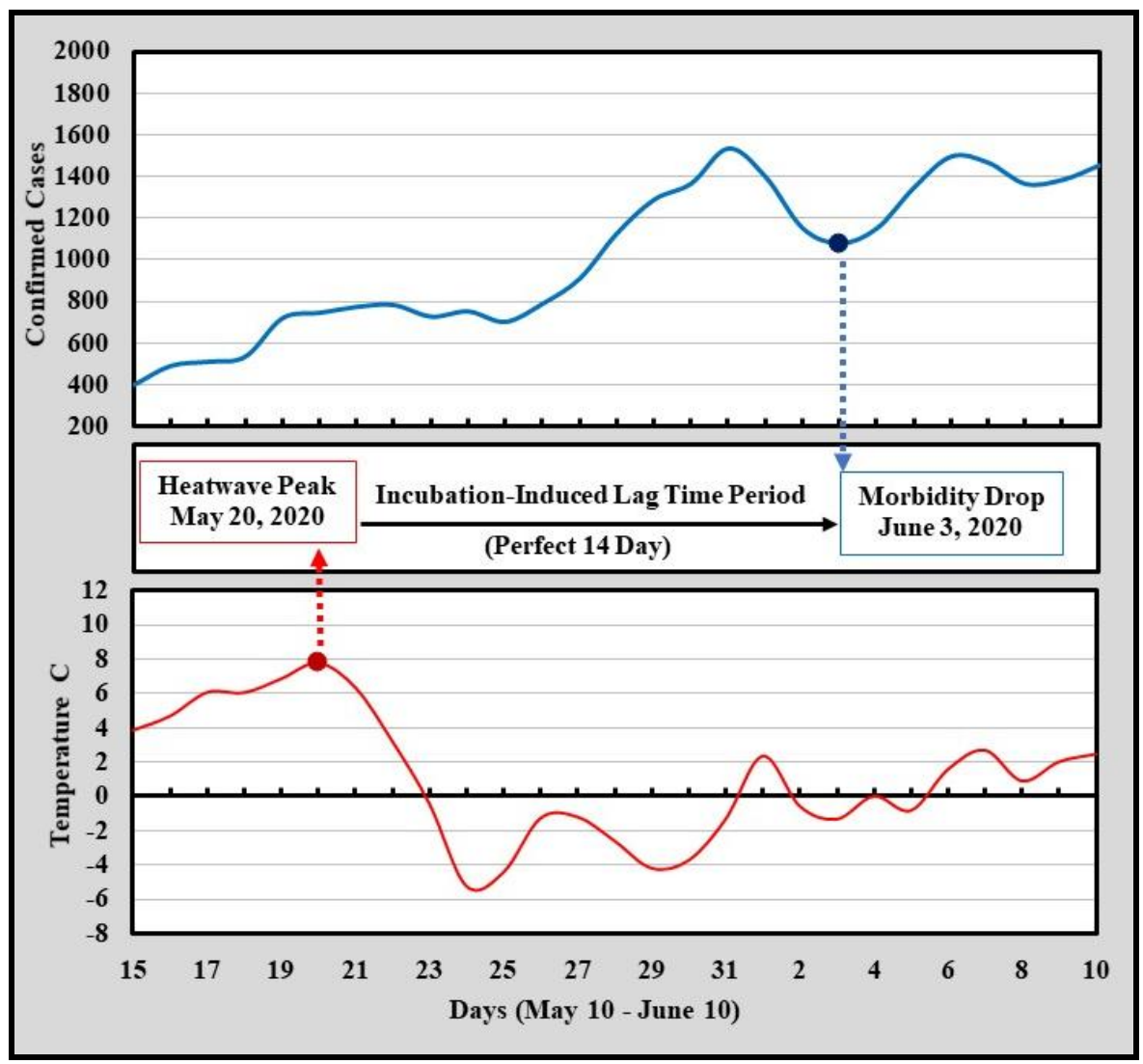

Figure 6. Connection between daily advancement of spatially averaged heatwave intensities (Bottom) and COVID-19 confirmed new cases (Top) in Egypt. 14-day incubation period of Corona virus and the resultant lag time are illustrated.

While the thermal intensity maximalcalculated during the heatwave is $7.8{ }^{\circ} \mathrm{C}$ occurred on May 20, the greatest decline in COVID-19 morbidity existed on June 3; exactly 14 days after. This minimal of COVID-19 infected caseswere 1079 cases, registered after the main top in cases of 1536 on May 31. This implicitly means that a strong heatwave intensity of $7.8{ }^{\circ} \mathrm{C}$ could mitigate COVID-19 morbidity by about onethird (1536 cases to 1079 cases). Overall, the spatially averaged 5-day heatwave (17-21 May) with thermal intensities 6.1-7.8 ${ }^{\circ} \mathrm{C}$ led to avis-a-vis 5-day fall (1-5 June) in COVID-19 morbidity of $1079-1399$ cases.

The main findings unveiled plainly in the treatment above on the country-level analysis are likewise keeping persistent in a more detailed level; i.e. within the Egyptian governorates. Take the most infected governorates of the capital region as examples; Cairo area witnesseda 6-day 
heatwave and thermal intensities $6.1-9.8{ }^{\circ} \mathrm{C}$. After exact 14 days of incubation period, COVID-19 confirmed cases decreased by $57.5 \%$ (852 cases to 362 cases) in Cairo (the first-largest infected governorate), and by $50 \%$ (572 cases to 286 cases) in Giza (the second-largest infected governorate), and by $61.1 \%$ (136 cases to 53 cases) in Qalyubia (the thirdlargest infected governorate).

Towards a more conceptualized framework of the relationship, Fig.7 is a scatter plot depicts the relationship between positive thermal intensity (daily average maximum temperature subtracts normal maximum temperature $\geq$ zero) and COVID-19 new conformed. The second order polynomial regression model for the relationship is also appended, both for observed and projected datapoints. The chart reveals that positive thermal intensity $\leq 5.5^{\circ} \mathrm{C}$ (data points in blue) has no effect on COVID-19 morbidity since there is an increase in confirmed cases despite positive thermal intensity increases as well. Whenpositive thermal intensity surpasses $5.5^{\circ} \mathrm{C}$ (data points in red), COVID-19 morbidity begins to bereduced. So, we can say that the critical thermal threshold at which COVID-19 morbidity declines is $5.5{ }^{\circ} \mathrm{C}$. moreover, the forward projection of that association proposes the thermal intensity of $10.7{ }^{\circ} \mathrm{C}$ as a critical thermal threshold at which COVID-19 morbidity may pause.

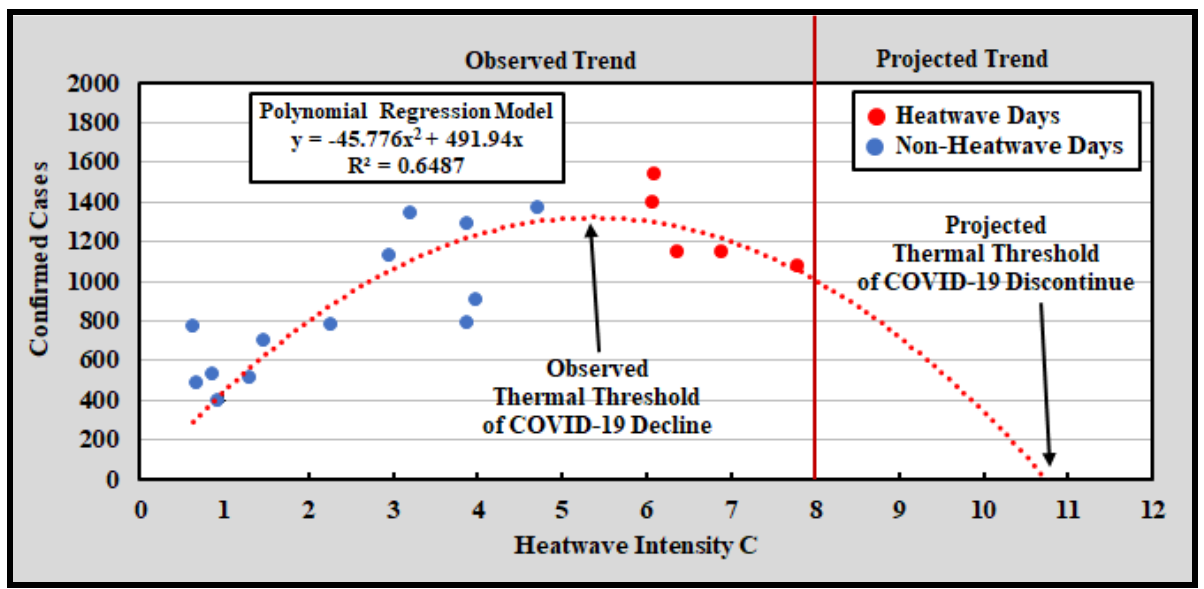

Credits: Regression analysis calculations.

Figure 7. Scatter plot and $2^{\text {nd }}$ order polynomial regression fit line of the linkage between real-time positive thermal intensity and 14-day backtracked COVID-19 new confirmed cases.

Uncertainty Evaluation of the previous $2^{\text {nd }}$ order polynomial regression model specified that ithas a valid performance. The correlation coefficient (R) of the overall model is high $(0.81)$. The coefficient of determination $\left(\mathrm{R}^{2}\right)$ 
is hence 0.65 , meaning that the model can explain $65 \%$ of COVID-19 morbidity behavior in Egypt. The inferential statistics indicate that the regression model results are reliable and significant, at confidence level of 99\% (P-value 0.00024). The model can also work well forecasting COVID19 morbidity in terms of confirmed new cases, by applying the following $2^{\text {nd }}$ order polynomial regression equation:

$$
y=-45.776 x^{2}+491.94 x
$$

Where: $y$ is COVID-19 morbidity (confirmed cases) and $x$ is thermal intensity $\left({ }^{\circ} \mathrm{C}\right)$ of heatwave. The standard error of the predicted value is \pm 191.2 .

In reference to the aforementioned, the late spring heatwave of 2020 was an outstanding weather event in Egypt. Now, although the outbreak of a pandemic is controlled by a variety of biological, health, political, social, economic and environmental factors, the results of this study offered a direct and proven relationship between the extremethermal circumstances and the newly discovered COVID-19 prevalence during the intense heatwave that Egypt was exposed to. This hypothesis can be tested in other contiguous countries in vicinity of Egypt, which were exposed to the same heatwave, such as Libya. It has been confirmed that the heatwaves have a significant impact on limiting the spread of COVID-19. Despite a few papers concluded no evidence for its temperature-dependence (BrizRedón \& Serrano-Aroca, 2020; Jamil, et al., 2020; Xie \& Zhu, 2020), our finding is agreed with the widely accepted fact provided by both epidemiological and laboratory studies (Araujo \& Naimi, 2020; Bukhari \& Jameel, 2020; Prata, et al., 2020; Sajadi, et al., 2020; Shi, et al., 2020) that increased exposure to heat has an effect on reducing the spread of epidemic diseases, resulting in decreased morbidity across a variety of climatic regions.

\section{Conclusion and Recommendations.}

The analysis and discussion above tackled COVID-19 outbreak in Egypt and, more deeply, the concurrent late spring heatwave of mid-May. Finally, it investigated the possible impact of that extreme temperature event on the pandemic morbidity. Many significant findings and discoveries were yielded. Despite the upward tendency of COVID-19 outbreak curve over Time, up and down swings were noticed. The main summit appears on the curve (May 31) followed by sudden decline, dropped by about onethird (June 3). Concurrently, the severe thermal conditions dominated over Egypt in May 16-21 were classified as advection heatwave. It was developed mainly because the prevailing temperaturemoderating northwesterly winds changed to northeasterly, southeasterly and southerly air masses coming from much hotter source regions in the Arabian Peninsula and Sudan. This synoptic situation caused by the extension of two thermal monsoonal lows toward Egypt; the IML and SML. 
The main conclusion derived from the analysis is that extreme temperature events of late spring can effectively restrict COVID-19 pandemic outbreak in terms of reducing morbidity level in warm arid environments like Egypt. Although heatwaves are risky climatic phenomenon and have adverse impacts on human health, it is proven to cause a beneficial effect of noticeabledecline in the Novel Coronavirus infectivity. The polynomial regressionmodel built works well to conceptualize the relationship and forecast infected cases based on heatwave intensity, with high confidence and low uncertainty. Giventhe abovementioned impact, COVID-19 outbreak is highly expected to be restricted as the temperatures increase with the advance of summer season.

The studyrecommendsthat lag timeresulted from the virus incubation period must be taken into account in any research that handles the COVID-19 mortality and morbidity. Future studies of the same approach should be carried out in different environments, for instance temperate and more humid climates, in order to establish a wide solid knowledge helping mitigate the worldwide COVID-19 pandemic.

\section{Declaration of Competing Interest}

The authors declare they have no conflicting interests.

\section{Funding Statement}

The authors received no specific funding for this work.

\section{References}

1. Abi-Samra, N. (2017): Power Grid Resiliency for Adverse Conditions, Artech House Publishers, Norwood, United States, 280 p. [ISBN: 9781630810177].

2. American Meteorological Society AMS (2012): Glossary of Meteorology, URL: http://glossary.ametsoc.org/wiki/Main_Page, Accessed June 1, 2020.

3. Araujo, M.B. and Naimi, B. (2020): Spread of SARS-CoV-2 Coronavirus Likely to be Constrained by Climate, medRxiv. [https://doi.org/10.1101/2020.03.12.20034728].

4. Backer, J.A., Klinkenberg, D. and Wallinga, J. (2020): Incubation Period of 2019 Novel Coronavirus (2019-nCoV) Infections Among Travellers from Wuhan, China, 20-28 January 2020, Eurosurveillance, 25 (5). [https://doi.org/10.2807/1560-7917.ES.2020.25.5.2000062].

5. Barbier, J., Guichard, F., Bouniol, D., Couvreux, F. and Roehrig, R. (2018): Detection of Intraseasonal Large-Scale Heat Waves: Characteristics and Historical Trends during the Sahelian Spring, J. Climate: 31 (1), 61-80. [https://doi.org/10.1175/JCLI-D-17-0244.1].

6. Briz-Redón, A. \& Serrano-Aroca, A. (2020): A Spatio-temporal Analysis for Exploring the Effect of Temperature on COVID-19 Early Evolution in Spain, Science of the Total Environment: 728, 138811. [https://doi.org/10.1016/j.scitotenv.2020.138811]. 
7. Bukhari, Q. and Jameel, Y. (2020): Will Coronavirus Pandemic Diminish by Summer? SSRN Electron.J. [https://doi.org/10.2139/ssrn.3556998].

8. Chan, K.H., Peiris, J.S., Lam, S.Y., Poon, L.L., Yuen, K.Y., Seto, W.H. (2011): The Effects of Temperature and Relative Humidity on the Viability of the SARS Coronavirus, Adv. Virol.: Vol. 2011, 734690.

[https://doi.org/10.1155/2011/734690].

9. Casanova, L.M., Jeon, S., Rutala,W.A.,Weber, D.J. and Sobsey, M.D. (2010): Effects of Air Temperature and Relative Humidity on Coronavirus Survival on Surfaces. Appl. Environ. Microbiol: 76 (9), 2712-2717.

[https://doi.org/10.1128/AEM.02291-09]

10. Dowell, S.F., Whitney, C.G., Wright, C., Rose, C.E. and Schuchat, A. (2003): Seasonal Patterns of Invasive Pneumococcal Disease. Emerging Infect. Dis: 9 (5), 574-579. [https://dx.doi.org/10.3201/eid0905.020556].

11. Dowell, S.F. and Ho, M.S. (2004): Seasonality of Infectious Diseases and Severe Acute Respiratory Syndrome - What We Don't Know Can Hurt Us, The Lancet Infect. Dis: 4 (11), 704-708 [https://doi.org/10.1016/S1473-3099(04)01177-6].

12. Egyptian Meteorological Authority EMA (1996): Climatic Atlas of Egypt. Cairo, $157 \mathrm{p}$.

13. El-Fandy, M.G. (1948): The Effect of the Sudan Monsoon Low on the Development of Thundery Conditions in Egpyt, Palestine and Syria, Q. J.R. Meteorol. Soc: 74 (319), 31-38. [https://doi.org/10.1002/qj.49707431904].

14. Ficetola, G.F. and Rubolini, D. (2020): Climate Affects Global Patterns of COVID19 Early Outbreak Dynamics, medRxiv, [https://doi.org/10.1101/2020.03.23.20040501].

15. Frich, P., Alexander, L.V., Della-Marta, P., Gleason, B., Haylock, M., Klein Tank, A.M.G. and Peterson, T. (2002): Observed Coherent Changes in Climatic Extremes during the Second Half of the Twentieth Century, Climate Research: 19, 193-212. [https://doi.org/10.3354/cr019193].

16. Huang, R., Liu, M. and Ding, Y. (2020): Spatial-temporal Distribution of COVID19 in China and its Prediction: A Data-driven Modeling Analysis, J. Infect. Developing Countries: 14 (3), 246-253. [https://doi.org/10.3855/jidc.12585].

17. IPCC (2013) Climate Change 2013: The Physical Science Basis. Contribution of Working Group I to the Fifth Assessment Report of the Intergovernmental Panel on Climate Change [Stocker, T.F., D. Qin, G.-K. Plattner, M. Tignor, S.K. Allen, J. Boschung, A. Nauels, Y. Xia, V. Bex and P.M. Midgley (eds.)]. Cambridge University Press, Cambridge, United Kingdom and New York, NY, USA, 1535 pp.

18. Isaksen, T.B., Fenske, R.A., Hom, E.K., Ren, Y., Lyons, H. and Yost, M.G. (2016): Increased Mortality Associated with Extreme-heat Exposure in King County, Washington, 1980-2010, Int. J. Biometeorol:: 60 (1), 85-98. [https://doi.org/10.1007/s00484-015-1007-9].

19. Jamil, T., Alam, I., Gojobori, T. and Duarte, C.M. (2020): No Evidence for Temperature- Dependence of the COVID-19 Epidemic, medRxiv, [https://doi.org/10.1101/2020.03.29.20046706].

20. Johnson, H., Kovats, R.S., McGregor, G., Stedman, J., Gibbs, M., Walton, H., Cook, L., Black, E. (2005): The Impact of the 2003 Heatwave on Mortality and Hospital Admissions in England, Health Stat. Q.: 25, 6-11. [https://doi.org/10.2807/esm.10.07.00558-en]. 
21. Kent, S.T., McClure, L.A., Zaitchik, B.F., Smith, T.T., Gohlke, J.M. (2014): Heat Waves and Health Outcomes in Alabama (USA): the importance of Heat Wave Definition, Environ Health Perspect: 122 (2), 151-158. [http://dx.doi.org/10.1289/ehp.1307262].

22. Kottek, M., Grieser, J., Beck, C., Rudolf, B. and Rubel, F. (2006): World Map of the Köppen-Geiger Climate Classification Updated, MeteorologischeZeitschrift: 15 (3), 259-263. [https://doi.org/10.1127/0941-2948/2006/0130].

23. Kottek, M., Grieser, J., Beck, C., Rudolf, B. and Rubel, F. (2006): Worldmap of the Köppen-Geiger Climate Classification Updated, MeteorologischeZeitschrift: 15 (3), 259-263. [https://doi.org/10.1127/0941-2948/2006/0130].

24. Kudo, E., Song, E., Yockey, L.J., Rakib, T., Wong, P.W., Homer, R.J. and Iwasaki, A. (2019): Low ambient humidity impairs barrier function and Innate Resistance Against Influenza Infection, PNAS: 116 (22), 10905-10910. [https://doi.org/10.1073/pnas.1902840116].

25. Lamarre, A. and Talbot, P.J. (1989): Effect of $\mathrm{pH}$ and Temperature on The Infectivity of Human Coronavirus 229E. Can J Microbiol: 35 (10), 972-974. [https://doi.org/10.1139/m89-160].

26. Lauer, S.A., Grantz, K.H., Bi, Q., Jones, F.K. and Zheng, Q. (2020): The Incubation Period of Coronavirus Disease 2019 (COVID-19) From Publicly Reported Confirmed Cases: Estimation and Application, Ann Intern Med. [https://doi.org/10.7326/M20-0504].

27. Liu, J., Zhou, J., Yao, J., Zhang, X., Li, L., Xu, X., He, X.,Wang, B., Fu, S., Niu, T., Yan, J., Shi, Y., Ren, X., Niu, J., Zhu, W., Li, S., Luo, B. and Zhang, K. (2020): Impact of Meteorological Factors on the COVID-19 Transmission: Multi-city Study in China, Sci. Total Environ.: 726, 138513 [https://doi.org/10.1016/j.scitotenv.2020.138513].

28. Loh, T.P., Lai, F.Y.L., Tan, E.S., Thoon, K.C., Tee, N.W.S., Cutter, J. and Tang, J.W. (2011): Correlations Between Clinical Illness, Respiratory Virus Infections and Climate Factors in a Tropical Paediatric Population. Epidemiol. Infect.: 139 (12), 1884-1894. [https://doi.org/10.1017/S0950268810002955].

29. Ma, Y., Zhao, Y., Liu, J., He, X.,Wang, B., Fu, S., Yan, J., Niu, J., Zhou, J. and Luo, B. (2020): Effects of Temperature Variation and Humidity on the Death of COVID-19 in Wuhan, China, Sci. Total Environ: 724, 138226. [https://doi.org/10.1016/j.scitotenv.2020.138226].

30. Matthews, J.B.R. (Coordinating edt.) (2018) IPCC Glossary, IPCC SR1.5, 55 p.

31. Medina-Ramon, M. and Schwartz, J. (2007): Temperature, Temperature Extremes, and Mortality: A Study of Acclimatization and Effect Modification in 50 US Cities, Occup. Environ. Med.: 64 (12), 827-833. [https://doi.org/10.1136/oem.2007.033175].

32. Mendez-Lazaro, P.A., Perez-Cardona, C.M., Rodriguez, E., Martinez, O., Taboas, M., Bocanegra, A. and Mendez-Tejeda, R. (2016): Climate Change, Heat, and Mortality in the Tropical Urban Area of San Juan, Puerto Rico, Int. J. Biometeorol.: 62 (5), 699-707. [https://doi.org/10.1007/s00484-016-1291-z].

33. Milard, S. (2018): Synoptic Analysis and Forecasting: An Introductory Toolkit, Elsevier, 246 p. [ISBN: 9780128092569$].$

34. Oliveiros, B., Caramelo, L., Ferreira, N.C. and Caramelo, F. (2020): Role of Temperature and Humidity in the Modulation of the Doubling Time of COVID-19 Cases, medRxiv. [https://doi.org/10.1101/2020.03.05.20031872]. 
35. Prata, D.N., Rodriguesa, W. and Bermejo, P.H. (2020): Temperature Significantly Changes COVID-19 Transmission in (Sub) Tropical Cities of Brazil, Science of the Total Environment: 729, 138862. [https://doi.org/10.1016/j.scitotenv.2020.138862].

36. Robinson, P.J. (2000): On the Definition of a Heat Wave, J. Appl. Meteor.: 40 (4), 762 775. [https://doi.org/10.1175/1520-0450(2001)040<0762:OTDOAH>2.0.CO;2].

37. Reddy, P.P. (2015) Climate Resilient Agriculture for Ensuring Food Security, Springer, 373 p. [https://doi.org/10.1007/978-81-322-2199-9].

38. Sajadi, M.M., Habibzadeh, P., Vintzileos, A., Shokouhi, S., Miralles-Wilhelm, F. and Amoroso, A. (2020): Temperature and Latitude Analysis to Predict Potential Spread and Seasonality for COVID-19, SSRN Electronic Journal, 3550308. [https://doi.org/10.2139/ssrn.3550308].

39. Shi, P., Dong, Y., Yan, H., Li, X., Zhao, C., Liu,W., He, M., Tang, S. and Xi, S. (2020): The Impact of Temperature and Absolute Humidity on the Coronavirus Disease 2019 (COVID-19) Outbreak Evidence from China, medRxiv, [https://doi.org/10.1101/2020.03.22.20038919].

40. Sfîcă, L., Croitoru, A.E., Iordache, I., Ciupertea, A.F (2017): Synoptic Conditions Generating Heat Waves and Warm Spells in Romania, Atmosphere: 8 (3), 50. [https://doi.org/10.3390/atmos8030050].

41. Tan, J., Mu, L., Huang, J., Yu, S., Chen, B. and Yin, J. (2005): An Initial Investigation of the Association Between the SARS Outbreak and Weather: With the View of the Environmental Temperature and its Variation, J. Epidemiol Community Health: 59 (3), 186-192. [https://doi.org/10.1136/jech.2004.020180].

42. Tosepu, R., Gunawan, J., Effendy, D.S., Lestari, H., Bahar, H. and Asfian, P. (2020): Correlation Between Weatherand Covid-19 Pandemic in Jakarta,

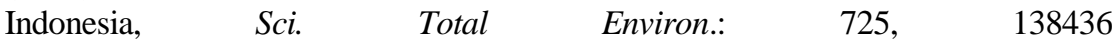
[https://doi.org/10.1016/j.scitotenv.2020.138436].

43. Van Doremalen, N., Bushmaker, T. and Munster, V.J. (2013) Stability of Middle East Respiratory Syndrome Coronavirus (MERS-CoV) Under Different Environmental Conditions, Euro Surveill: 18 (38). [https://doi.org/10.2807/15607917.es2013.18.38.20590].

44. Wallis, P. and Nerlich, B. (2005): Disease Metaphors in New Epidemics: the UK Media Framing of the 2003 SARS Epidemic, Soc. Sci. Med., 60 (11), 2629-2639. [https://doi.org/10.1016/j.socscimed.2004.11.031].

45. Wang, M., Jiang, A., Gong, L., Luo, L., Guo,W., Li, C. and Zeng, J. (2020): Temperature Significant Change COVID-19 Transmission in 429 Cities, medRxiv. [https://doi.org/10.1101/2020.02.22.20025791].

46. WMO (2015): Heatwaves and Health: Guidance on Warning-System Development, WMO-No. 1142, Geneva, 96 p.

47. WHO (15/2/2020): Coronavirus Disease 2019 (COVID-19) Situation Report - 26.

48. WHO (2/4/2020): Coronavirus Disease 2019 (COVID-19) Situation Report - 73.

49. WHO (2020a) Coronavirus Disease (COVID-19) Dashboard, https://covid19.who.int/, Accessed June 18, 2020.

50. WHO (2020b): METEOTERM: WMO Terminology Database, URL: https://public.wmo.int/en/resources/language\%20resources/meteoterm, Accessed June 1, 2020. 
51. Wilder-Smith, A., Chiew, C.J. and Lee, V.J. (2020): Can We Contain the COVID19 Outbreak with the Same Measures as for SARS? Lancet Infect. Dis.: 20 (5), E102-E107. [https://doi.org/10.1016/S1473-3099(20)30129-8].

52. Xie, J. and Zhu, Y. (2020): Association Between Ambient Temperature and Covid19 Infection in 122 Cities from China, Sci. Total Environ.: 724, 138201. [https://doi.org/10.1016/j.scitotenv.2020.138201].

53. Yin, P., Chen, R., Wang, L., Liu, C., Niu, Y., Wang, W., Jiang, Y., Liu, Y., Liu, J., Qi., J., You, J., Zhou, M. and Kan, H. (2018): The added effects of heatwaves on cause-specific mortality: A nationwide analysis in 272 Chinese cities, Environment International: 121 (1), 898-905. [https://doi.org/10.1016/j.envint.2018.10.016].

54. Zaki, N. and Mohamed, E.A. (2020): The Estimations of the COVID-19 Incubation Period: A Systematic Review of the Literature, MEDRXIV

[https://doi.org/10.1101/2020.05.20.20108340]. 


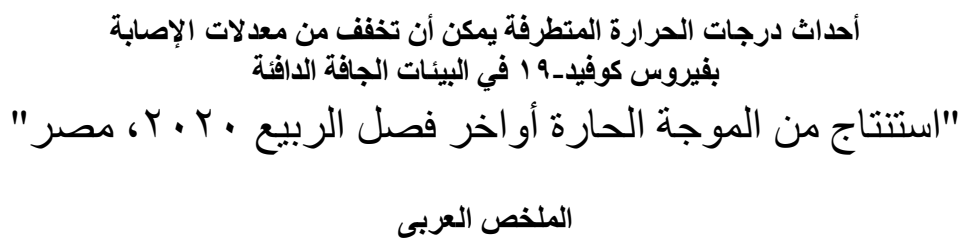

كان لظهور وانتشار جائحة كورونا تأثيرات سلبية كبيرة، الأمر الذي شكل أزمة عالمية ضخمة. وباعنبار درجة الحرارة مؤثر رئيسي في تقليل عدوى الأمراض الفيروسية، تنتاول الدراسة

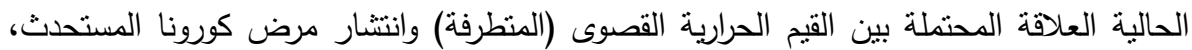

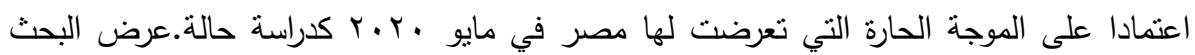

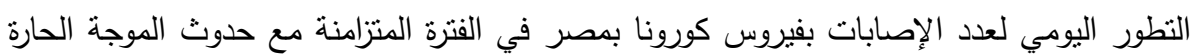
سابقة الذكر، والتي نم تحديدها وتحليل سماتها بشكل تفصيلي. أظهر التفسير البصري للأشكال البيانية وجود علاقة ارتباطية قوية جدا مثيرة للانتباه بين قوة الموجة الحارة وبين حالات الإصابة

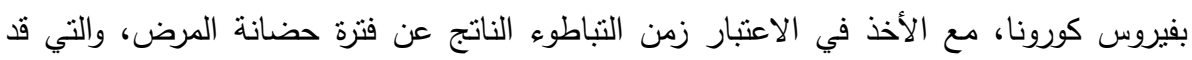

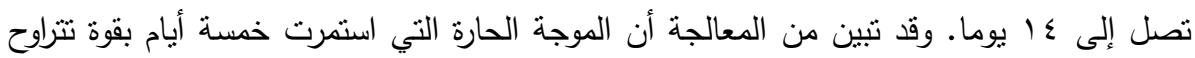

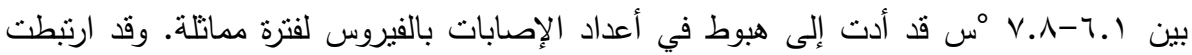
ذروة الموجة الحارة بأكبر تتاقص في عدد الإصابات، بنسبة وصلت إلى ما يقرب من الثلث. وقد بين التين

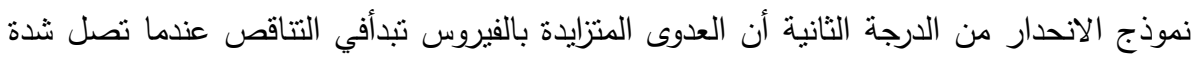

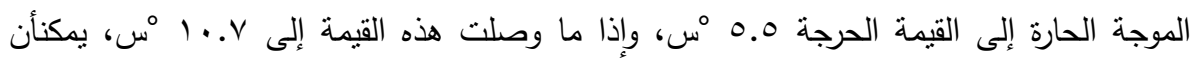

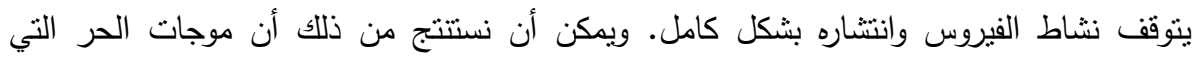
تشهدها مصر في أواخر فصل الربيع لها تأثير كبير في الدد من انتشار فيروس كورونا في البيئات

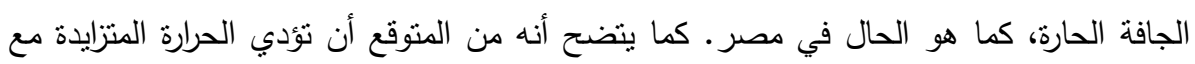
دخول فصل الصيفإلى مزيد من الانخفاض في معدلات العدوى بالمرض. وتوصي الدراسة بضرورة

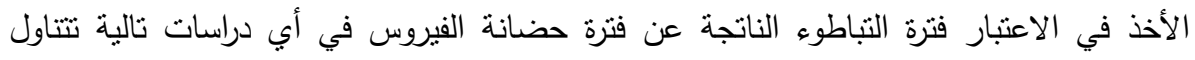
انتشار العدوى أو الوفيات الناتجة عن فيروس كورونا.

الكلمات المفتاحية: موجات الحر، فيروسات سارس، فيروس كورونا، الأمراض الوبائية أو الجائحة، نماذج الانحدار المتعدد، التحليل الثنامل (السينوبتي). 